\title{
Deformation-related volcanism in the Pacific Ocean linked to the Hawaiian-Emperor bend
}

\author{
John M. O'Connor ${ }^{1,2,3 \star}$, Kaj Hoernle ${ }^{4}$, R. Dietmar Müller ${ }^{5}$, Jason P. Morgan ${ }^{6}$, \\ Nathaniel P. Butterworth ${ }^{5}$, Folkmar Hauff ${ }^{4}$, David T. Sandwell ${ }^{7}$, Wilfried Jokat ${ }^{1,8}$, \\ Jan R. Wijbrans ${ }^{3}$ and Peter Stoffers ${ }^{9}$
}

\begin{abstract}
Ocean islands, seamounts and volcanic ridges are thought to form above mantle plumes. Yet, this mechanism cannot explain many volcanic features on the Pacific Ocean floor $^{1}$ and some might instead be caused by cracks in the oceanic crust linked to the reorganization of plate motions ${ }^{1-3}$. A distinctive bend in the Hawaiian-Emperor volcanic chain has been linked to changes in the direction of motion of the Pacific Plate ${ }^{4,5}$, movement of the Hawaiian plume ${ }^{6-8}$, or a combination of both ${ }^{9}$. However, these links are uncertain because there is no independent record that precisely dates tectonic events that affected the Pacific Plate. Here we analyse the geochemical characteristics of lava samples collected from the Musicians Ridges, lines of volcanic seamounts formed close to the Hawailan-Emperor bend. We find that the geochemical signature of these lavas is unlike typical ocean island basalts and instead resembles mid-ocean ridge basalts. We infer that the seamounts are unrelated to mantle plume activity and instead formed in an extensional setting, due to deformation of the Pacific Plate. ${ }^{40} \mathrm{Ar} /{ }^{39} \mathrm{Ar}$ dating reveals that the Musicians Ridges formed during two time windows that bracket the time of formation of the Hawaiian-Emperor bend, 53-52 and 48-47 million years ago. We conclude that the Hawaiian-Emperor bend was formed by plate-mantle reorganization, potentially triggered by a series of subduction events at the Pacific Plate margins.
\end{abstract}

Both changes in mantle flow ${ }^{6-8}$ and in the direction of Pacific Plate motion $^{4,5}$ have been proposed to explain the Hawaiian-Emperor bend (HEB). Decreasing palaeolatitudes during the formation of the Emperor Seamounts ${ }^{6,8}$, and combined global mantle flow and plate motion model ${ }^{5}$, support mantle flow as the dominant mechanism for creating the HEB. A palaeomagnetic pole for the Pacific Plate (based on the skewness of vector aeromagnetic profiles of magnetic anomalies due to seafloor spreading) has been interpreted as evidence that $5^{\circ} \pm 3^{\circ}$ of the southward motion of the Hawaiian hotspot occurred after $32 \mathrm{Myr}$ ago (ref. 10), thus post-dating the formation of the Emperor Seamounts, but the robustness of this type of analysis has been questioned (Supplementary Note 1). An alternative hypothesis notes the broad coincidence of the HEB with major circum-Pacific Plate tectonic events and favours HEB formation by the resulting change in the direction of Pacific Plate motion ${ }^{4,5,11,12}$. But plate reconstructions connecting the Indo-Atlantic realm to the Pacific for Late Cretaceous predict a negligible bend ${ }^{13}$.

Although diverse lines of evidence record a rough correlation between other circum-Pacific tectonic changes (Supplementary Note 2) and formation of the HEB (refs 5,11,14), their timing has been too protracted to establish a connection. Here we report the unexpected discovery of the long-sought-after independent temporal record of circum-Pacific tectonic events while investigating a new type of linear structure on the Pacific seafloor detected in recent years by improvements in satellite altimetry ${ }^{2}$. This new type of structure consists of groups of linear en échelon volcanic ridges, first described in 1987 for the 'Crossgrain' ridges located in the central Pacific $^{2}$. Mechanisms explaining these linear ridge groups include hotspot-spreading ridge interaction ${ }^{15}$ and tensional cracking of the Pacific Plate ${ }^{2,3}$ (see Supplementary Note 3).

To investigate the origin of these enigmatic structures, we carried out seismic surveys and dredge sampled the en échelon linear ridges, extending eastward in clusters, from the northern and southern ends of the Musicians Seamount Chain and the Murray Fracture Zone (FZ) on RV Sonne cruise SO142 (Fig. 1 and Supplementary Fig. 1 and Supplementary Table 1). The Musicians Seamounts form a NW trending age-progressive Cretaceous hotspot track, located several hundred kilometres northwest of the Hawaiian Seamounts, best explained by plate motion over a now extinct Musicians hotspot ${ }^{15,16}$. The cluster of ridges extending from the southern end of the Musicians Seamount Chain is bounded to the north by the Murray FZ, which consists of a $\sim 100 \mathrm{~km}$ band of linear ridges and troughs that stretch from the Musicians to the Hawaiian Seamount Chain ${ }^{16}$. We dredge sampled one of these volcanic ridges in the Murray FZ (Fig. 1).

Seismic profiles collected during the SO142 expedition show that the Musicians Ridges were formed by volcanism ${ }^{15}$. The volcanism is interpreted to have been generated by flow of mantle along channels in the base of the lithosphere from the Musicians hotspot to the Pacific-Farallon spreading centre in the Cretaceous ${ }^{15}$. Although this is consistent with the $\sim 94-92 \mathrm{Myr}{ }^{40} \mathrm{Ar} /{ }^{39} \mathrm{Ar}$ ages for two samples dredged from the volcanic ridge located furthest away from the northern end of the Musicians Chain (Fig. 1), most of the ${ }^{40} \mathrm{Ar} /{ }^{39} \mathrm{Ar}$ ages for the southern Musicians Ridges are unexpectedly 52-53 Myr. A few younger ages show that volcanism might have

\footnotetext{
${ }^{1}$ Alfred Wegener Institute, Helmholtz Centre for Polar and Marine Research, Am Alten Hafen 26, 27568 Bremerhaven, Germany. ${ }^{2}$ GeoZentrum Nordbayern, University Erlangen-Nürnberg, Schlossgarten 5, 91054 Erlangen, Germany. ${ }^{3}$ Faculty of Earth and Life Sciences, VU University Amsterdam, De Boelelaan 1085, 1081 HV Amsterdam, The Netherlands. ${ }^{4}$ GEOMAR Helmholtz Centre for Ocean Research Kiel, Wischhofstrasse 1-3, 24148 Kiel, Germany. ${ }^{5}$ EarthByte Group, School of Geosciences, The University of Sydney, New South Wales 2006, Australia. ${ }^{6}$ Department of Earth Sciences, Royal Holloway, University of London, Egham, Surrey TW20 OEX, UK. ${ }^{7}$ Institute of Geophysics and Planetary Physics, Scripps Institution of Oceanography, 9500 Gilman Drive, La Jolla, California 92093-0225, USA. ${ }^{8}$ University of Bremen, Fachbereich 5, 330440 Bremen, Germany. ${ }^{9}$ Institute for Geosciences, Christian-Albrechts-University, Ludewig-Meyn-Str. 10, 24118 Kiel, Germany. *e-mail: j.m.oconnor@vu.nl
} 

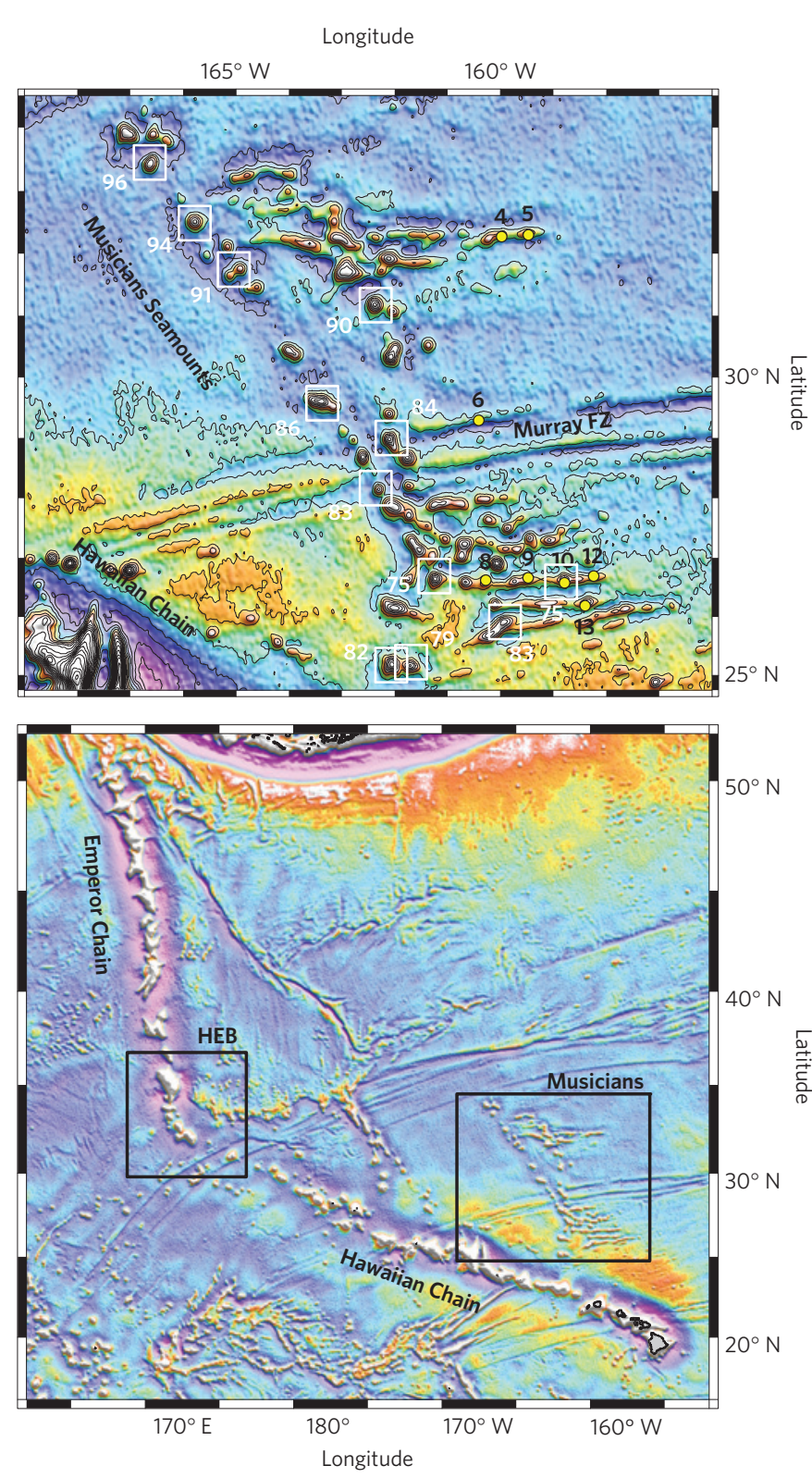

Figure 1 | Locations of sample sites on the Musicians volcanic ridges.

Yellow circles in the top panel indicate the locations of SO142 expedition dredge sites and adjacent numbers give the station numbers

(see Supplementary Table 1 for sample information). Sample ages are shown also on high-resolution bathymetric maps in Supplementary Fig. 1. The base map is marine gravity from radar altimetry at a contour interval of $20 \mathrm{mGal}$ (ref. 31). White numbers are for published ages measured in the 1990 s and white boxes show sample locations ${ }^{16}$. The box around the HEB marks the position of an enlarged map with age information in Supplementary Fig. 3.

continued until 47-48 Myr ago, or that a second event occurred roughly $6 \mathrm{Myr}$ later. Surprisingly, the samples from the Murray FZ also yielded ages of $47-48 \mathrm{Myr} .{ }^{40} \mathrm{Ar} /{ }^{39} \mathrm{Ar}$ plateau ages are shown in Fig. 2 and Supplementary Fig. 2. For complete information see Methods, Supplementary Table 2 and Supplementary Methods. The most striking facet of these unexpectedly young lava ages is they bracket the formation of the HEB (50-47 Myr ago; refs 5,9; see also Supplementary Fig. 3).

The geochemistry of this late-stage volcanism can help constrain its origin (Fig. 3 and Supplementary Fig. 4 and Supplementary Table 2). The dated samples are unlike rejuvenated
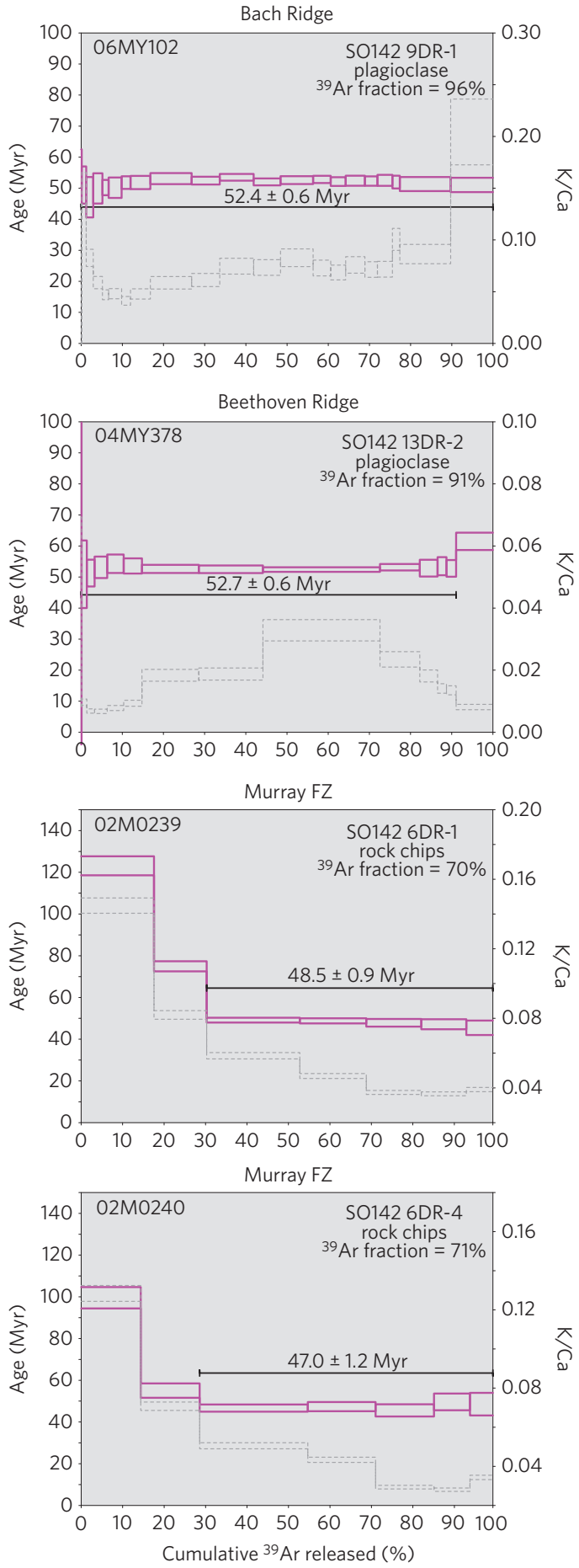

Figure 2 | Examples of high-resolution incremental heating ${ }^{40} \mathrm{Ar} /{ }^{39} \mathrm{Ar}$ age spectra for the Musicians volcanic ridges. Pink lines are ${ }^{40} \mathrm{Ar} /{ }^{39} \mathrm{Ar}$ ages, and grey lines are $\mathrm{K} / \mathrm{Ca}$ ratios. The reported ${ }^{40} \mathrm{Ar} /{ }^{39} \mathrm{Ar}$ age ages are weighted age estimates with errors reported on the $95 \%$ confidence level, including $0.3 \%-0.4 \%$ s.d. in the $J$-value. All samples where monitored against Taylor Creek rhyolite (TCR) monitor (28.34 \pm 0.014 Myr, $1 \sigma)$. For complete information see Methods, Supplementary Table 2,

Supplementary Fig. 2 and Supplementary Methods.

(or post-erosional) volcanism found on intraplate volcanoes, such as the Hawaiian Island volcanoes, because they are tholeiitic and are depleted in both incompatible element and isotopic composition, whereas rejuvenated volcanism is alkalic and shows incompatible element enrichment (see also Supplementary Note 4). 

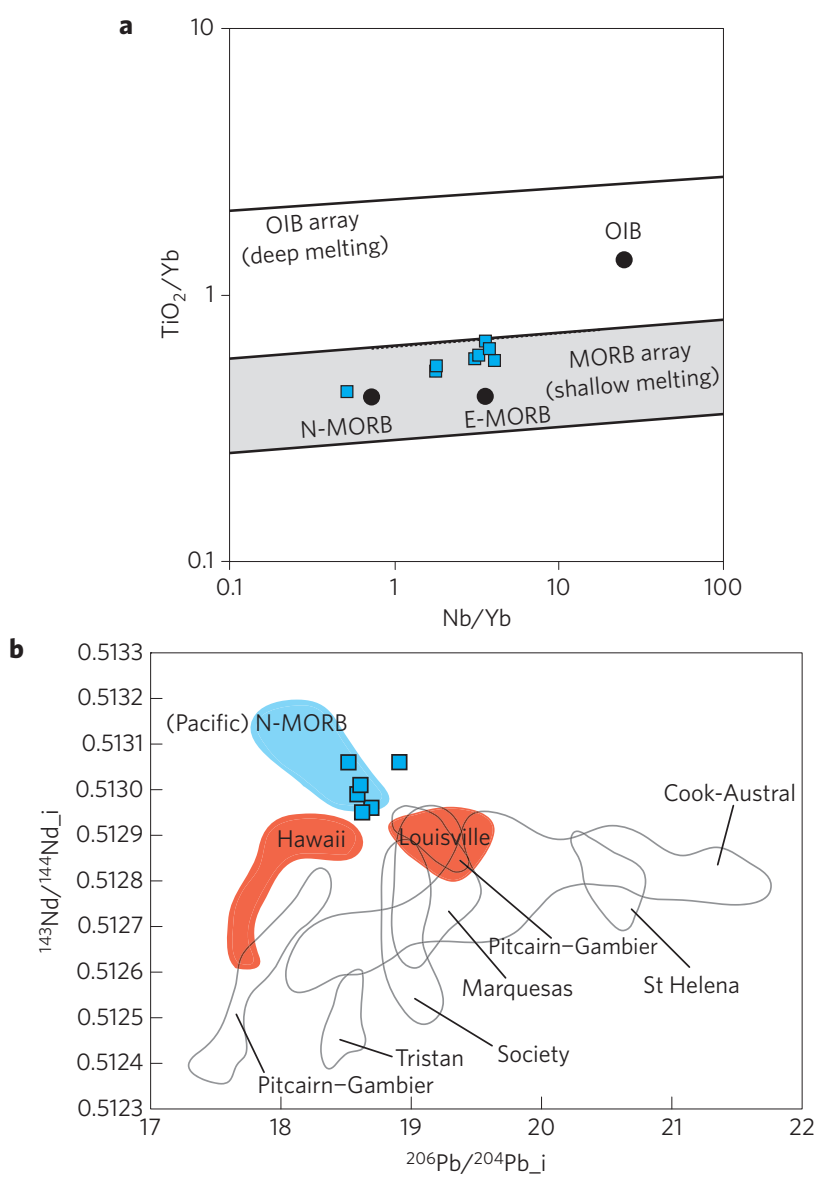

Figure 3 | Evidence that deformation volcanism is related to a depleted upper mantle source. $\mathbf{a}, \mathrm{Nb} / \mathrm{Yb}$ versus $\mathrm{TiO}_{2} / \mathrm{Yb}$ discrimination diagram. Fractionation of Ti from $\mathrm{Yb}$ by garnet provides a proxy for depth of melting. MORB forms a shallow array, and basalts with significant residual garnet (that is, Ocean Island basalt (OIB)) plot above the array. b, Isotopic compositions of Musicians lavas (this study) are age-corrected using ages reported here. Representative island (OIB) groups (in red) are from the GEOROC database (http://georoc.mpch-mainz.gwdg.de) and the field for Pacific N-MORB (in blue) is from the PETDB database

(http://www.petdb.org) and is age-corrected to $57 \mathrm{Myr}$ ago. Panel a reproduced with permission from ref. 33, Elsevier.

The late-stage Musicians lavas have similar major element, trace element and $\mathrm{Sr}-\mathrm{Nd}-\mathrm{Pb}$ isotopic compositions to mid-ocean ridge basalts (MORB), consistent with their derivation from shallow upper mantle sources, despite not having been formed at a mid-ocean ridge.

The best and most obvious explanation for this new type of MORB-like, non-hotspot intraplate volcanism is that it records increased plate deformation that caused magmatism through decompression melting with plate cracking (reactivation of Cretaceous linear features), possibly facilitating and focusing magma ascent (see, for example, refs 2,3 ). Some possible presentday analogues for the type of deformation and volcanism that we invoke here for the early Tertiary are the en échelon ridges in the extensional part of the Capricorn-Australia plate boundary ${ }^{17}$, as well as the Pukapuka Ridges in the central Pacific ${ }^{18}$. Another analogue might be located to the west of the Mid-Atlantic Ridge, where the Researcher volcanic ridge and graben system to the north form an en échelon volcano-tectonic complex that is extensional in character (Supplementary Note 5).

There is evidence also in the geologic record to show that subduction forces can cause plate yielding ${ }^{19}$ (Supplementary Note 6).
For example, there is extensive geologic evidence indicating that subduction initiation along the western Pacific caused the tectonic events surrounding the Pacific, and led to the onset of uplift of the Transantarctic Mountains (Supplementary Note 2). It seems reasonable, therefore, to infer from the striking synchronicity between the 53-52 Myr ago tectonic-magmatic event and subduction of the Izanagi-Pacific spreading ridge ( $\sim 52-51$ Myr ago; refs 11,20), and subduction initiation at the Izu-Bonin-Marianas subduction zone (IBM) and Tonga ( 51.5 Myr ago, as measured by subductionrelated volcanism $)^{19,21-23}$, that they might be causally connected (Fig. 4). Moreover, the initiation of Aleutian subduction, at end of this subduction zone reorganization ${ }^{24,25}$, coincides with the observed 47-48 Myr ago magmatism.

If increased stress within the plate was the sole mechanism controlling the location and timing of this new style of MORBlike intraplate volcanism, then it is likely to be distributed widely across the Pacific seafloor. As relatively few intraplate structures in the Pacific have been sampled and dated, we do not know if there is evidence for widespread deformation-related volcanism between 52-53 and 47-48 Myr ago. Nevertheless, local plate and shallow mantle melting and flow anomalies are likely to determine where MORB-like intraplate volcanism occurs during intervals of increased plate stress (see Supplementary Note 3).

Current numerical models of the subduction-related forces driving the Pacific Plate do not incorporate local plate and mantle anomalies, and so cannot predict where and when plate cracking and decompression melting might trigger intraplate volcanism across the Pacific Plate. Numerical modelling, however, does point to the possibility that a major plate-wide change in subduction topology between 62 and $52 \mathrm{Myr}$ ago might have led to an increase in plate speed and intraplate deformation across the Pacific Plate ${ }^{26}$.

A possible plate-scale mechanism for changing asthenospheric flow might be a gradual westward speed-up of the Farallon-Pacific spreading rates, possibly starting at $\sim 50$ Myr ago, which was caused by the increasing pull on the Pacific Plate exerted by the subducting slabs in the IBM and Tonga subduction zones ${ }^{20,26}$. This timing corresponds to the part of the Hawaiian-Emperor Seamount Chain where the trend first starts to rotate from nearly due south to east-southeast, just north of Daikakuji and near Kimmei Seamount, marking the time of inception of the HEB $\geq 50 \mathrm{Myr}$ ago and not the most arcuate $47.5 \mathrm{Myr}$ ago part on the bend ${ }^{5,9}$ (see also Supplementary Fig. 3).

Increasing pull from the IBM and Tonga subducing slabs could have caused Pacific Plate speed-up at $~ 50$ Myr ago (refs 20,26), and might have gradually changed the resistance or dragging force associated with the interface between the upper mantle and plate (basal drag or basal shear force), which is usually considered to act in an opposite direction to absolute motion ${ }^{27}$. As the plate accelerated to the northwest, asthenosphere counterflow could have increased in the opposite direction, deflecting the Hawaiian plume to the southeast during its final ascent through the transition $z^{2} e^{28}$, reflected in the change in the trend of the Emperor Chain at Kimmei Seamount.

A change in asthenosphere flow at $\sim 50 \mathrm{Myr}$ ago might also have initiated the start of final plume slowdown ${ }^{9}$ before the sharp 47.5 Myr ago HEB. This shallow mantle mechanism would fit with an explanation for plume motion and slowdown involving a capture and release mechanism, which also involves plate processes in the form of waning Kula-Pacific spreading ${ }^{13}$. A further change in the basal drag force might have resulted from initiation of subduction to the north in the Aleutians at the time of the sharp HEB.

In summary, the apparent reactivation of the Cretaceous Musicians Ridges started at the same time as a series of major inter-connected subduction events around the Pacific margins. Local factors, such as lithospheric age and structure (see, for example, refs 2,3,18), possibly by operating in combination with other types of secondary small-scale sub-lithospheric convection ${ }^{29}$, 
a

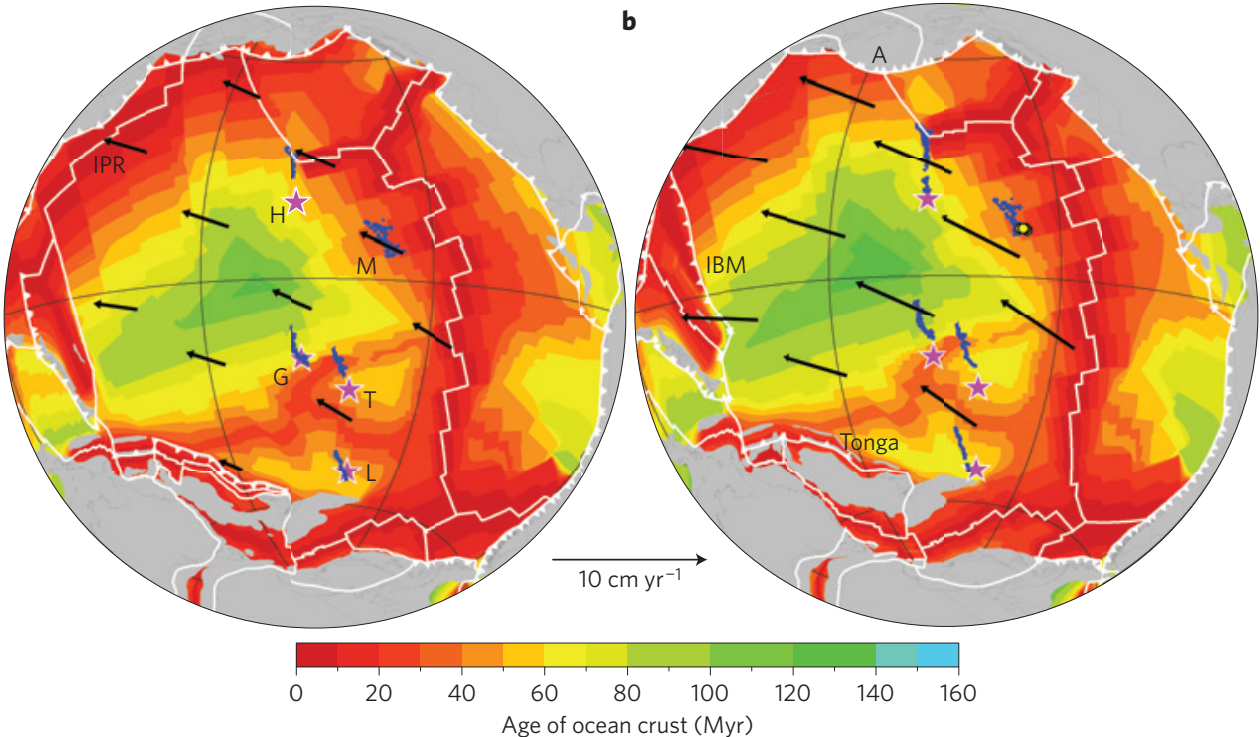

Figure 4 | Reconstruction of plates and plate boundaries around the Pacific Ocean Basin. a, Before the HEB (62 Ma). b, After the HEB (42 Ma). Plate boundaries are shown in white; hotspots are magenta stars and hotspot tracks are in dark blue; yellow circles delineate deformation volcanism: A-Aleutian subduction zone, IBM-Izu-Bonin-Marianas subduction zone, IPR-Izanagi-Pacific Ridge, M-Musicians Seamounts; hotspots: H-Hawaii, G-Gilbert, T-Tokelau, L-Louisville. Data for the rotations and plate boundary configurations are from ref. 12, palaeo-age of the ocean crust from ref. 32 , and Pacific absolute plate motion velocities from ref. 26 stage rotations.

no doubt influenced the location of late-stage, MORB-like intraplate volcanism. For example, the $\sim 75 \mathrm{Myr}$ ago and $\sim 57 \mathrm{Myr}$ ago HEtype bends in the Gilberts and Tokelau seamount chains are linked to reactivation of preconditioned lithosphere by jerk-like plate extensions in the Pacific Plate ${ }^{30}$. The HEB began at $\geq 50$ Myr ago (refs 5,9), when pull from these subducting slabs was sufficient to change Pacific Plate motion, which we infer could have triggered a change in asthenospheric flow.

In conclusion, based on the timing and geochemistry of an unusual MORB-type of intraplate volcanism, we propose that subduction initiation events along the western and northern Pacific, respectively, caused internal plate deformation that might have triggered magmatism due to decompression melting, possibly associated with cracking of the upper oceanic plate and other local plate and shallow mantle mechanisms. We infer that the HEB morphology and a slowdown in posited plume motion correlate with changes in asthenosphere flow resulting from plate speed-up caused by increasing pull on the Pacific Plate following subduction of the Izanagi-Pacific Ridge and initiation of Aleutian subduction. Thus, the HEB might be linked to subduction-driven asthenospheric changes at a time when the rapidly moving Hawaiian plume was slowing down. Such a model is compatible with current estimates of plume motion based on drill-site palaeolatitude information ${ }^{6}$ and could be further tested with new, very deep drill sites, because only with these will there be any hope of constraining changes of motion within the overall southward drift.

This new style of non-hotspot-related intraplate volcanic reactivation represents a potentially powerful new proxy for identifying and dating intraplate deformation caused by plate reorganization events. Depending on the scale of asthenosphere changes, deflection and smearing out of plumes in the shallow mantle related to such events might correlate with regional or platewide changes in the motion and volume flux of hotspot tracks, and account for at least some of the non-age-progressive' intraplate volcanism widely found across the Pacific ${ }^{1}$.

\section{Methods}

The ArArCALC ${ }^{40} \mathrm{Ar} /{ }^{39} \mathrm{Ar}$ age data files in Microsoft Excel format are provided in the Supplementary Information. Further details are outlined in the Supplementary Methods.
Code availability. The ArArCALC v2.5 software used to calculate the ${ }^{40} \mathrm{Ar} /{ }^{39} \mathrm{Ar}$ ages is available at http://earthref.org/ArArCALC.

Received 17 October 2014; accepted 13 March 2015; published online 27 April 2015

\section{References}

1. Koppers, A. A. P. Mantle plumes persevere. Nature Geosci. 4, 816-817 (2011).

2. Winterer, E. L. \& Sandwell, D. T. Evidence from en échelon cross-grain ridges for tensional cracks in the Pacific Plate. Nature 329, 534-537 (1987).

3. Natland, J. H. \& Winterer, E. L. in Plates, Plumes, and Paradigms Vol. 388 (eds Foulger, G. R., Natland, J. H., Presnall, D. C. \& Anderson, D. L.) 687-710 (Geological Society of America Special Paper, Geol. Soc. Am., 2005).

4. Gordon, R. G., Cox, A. \& Harter, C. E. Absolute motion of an individual plate estimated from its ridge and trench boundaries. Nature 274, 752-755 (1978)

5. Sharp, W. D. \& Clague, D. A. 50-Ma Initiation of Hawaiian-Emperor bend records major change in Pacific Plate motion. Science 313, 1281-1284 (2006)

6. Tarduno, J. A. et al. The Emperor Seamounts: Southward motion of the Hawaiian hotspot plume in Earth's mantle. Science 301, 1064-1069 (2003).

7. Steinberger, B., Sutherland, R. \& O'Connell, R. J. Prediction of Emperor-Hawaii Seamount locations from a revised model of global plate motion and mantle flow. Nature 430, 167-173 (2004).

8. Tarduno, J. A. On the motion of Hawaii and other mantle plumes. Chem. Geol. 241, 234-247 (2007)

9. O'Connor, J. M. et al. Constraints on past plate and mantle motion from new ages for the Hawaiian-Emperor Seamount Chain. Geochem. Geophys. Geosyst. 14, 4564-4584 (2013).

10. Horner-Johnson, B. C. \& Gordon, R. G. True polar wander since 32 Ma B. P. A paleomagnetic investigation of the skewness of magnetic anomaly $12 \mathrm{r}$ on the Pacific Plate. J. Geophys. Res. 115, B09101 (2010).

11. Whittaker, J. M. et al. Major Australian-Antarctic plate reorganization at Hawaiian-Emperor bend time. Science 318, 83-86 (2007).

12. Seton, M. et al. Global continental and ocean basin reconstructions since 200 Ma. Earth-Sci. Rev. 113, 212-270 (2012).

13. Tarduno, J., Bunge, H-P., Sleep, N. \& Hansen, U. The bent Hawaiian-Emperor hotspot track: Inheriting the mantle wind. Science 324, 50-53 (2009).

14. Wessel, P., Harada, Y. \& Kroenke, L. W. Toward a self-consistent, high-resolution absolute plate motion model for the Pacific. Geochem. Geophys. Geosyst. 7, Q03L12 (2006).

15. Kopp, H., Kopp, C., Phipps Morgan, J., Flueh, E. R. \& Weinrebe, W. Fossil hot spot-ridge interaction in the Musicians Seamount Province: Geophysical investigations of hot spot volcanism at volcanic elongated ridges. J. Geophys. Res. 108, 2160 (2003). 
16. Pringle, M. S. in The Mesozoic Pacific: Geology Tectonics and Volcanism (eds Pringle, M., Sager, W. \& Sliter, W.) 187-215 (Geophysical Monograph Series 77, AGU, 1993).

17. Royer, J-Y. \& Gordon, R. G. The motion and boundary between the Capricorn and Australian plates. Science 277, 1268-1274 (1997).

18. Sandwell, D. T. et al. Evidence for diffuse extension of the Pacific Plate from Pukapuka Ridges and cross-grain gravity lineations. J. Geophys. Res. 100, 15087-15099 (1995).

19. Matthews, K. J. et al. Geological and kinematic constraints on Late Cretaceous to mid Eocene plate boundaries in the Southwest Pacific. Earth-Sci. Rev. 140, 72-107 (2015).

20. Engebretson, D. C., Cox, A. \& Gordon, R. G. Relative motions between oceanic plates of the Pacific Basin. J. Geophys. Res. 89, 10291-10310 (1984).

21. Reagan, M. K. et al. The geology of the southern Mariana fore-arc crust: Implications for the scale of Eocene volcanism in the western Pacific. Earth Planet. Sci. Lett. 380, 41-51 (2013).

22. Meffre, S. et al. Basalts erupted along the Tongan fore arc during subduction initiation: Evidence from geochronology of dredged rocks from the Tonga fore arc and trench. Geochem. Geophys. Geosyst. 13, Q12003 (2012).

23. Ishizuka, O. et al. The timescales of subduction initiation and subsequent evolution of an oceanic island arc. Earth Planet. Sci. Lett 306, 229-240 (2011).

24. Jicha, B. R., Scholl, D. W., Singer, B. S., Yogodzinski, G. M. \& Kay, S. M. Revised age of Aleutian Island Arc formation implies high rate of magma production. Geology 34, 661-664 (2006).

25. Höfig, T. W. et al. in Am. Geophys. Union Fall Meet. 2013 Abstract V21C-2742 (AGU, 2013).

26. Butterworth, N. P. et al. Pacific Plate slab pull and intraplate deformation in the early Cenozoic. Solid Earth 5, 757-777 (2014).

27. Forsyth, D. W. \& Uyeda, S. On the relative importance of the driving forces of plate motion. Geophys. J. R. Astron. Soc. 43, 163-200 (1975).

28. Ballmer, M. D., Ito, G., Wolfe, C. J. \& Solomon, S. C. Double layering of a thermochemical plume in the upper mantle beneath Hawaii. Earth Planet. Sci. Lett. 376, 155-164 (2013).

29. Ballmer, M., van Hunen, J., Ito, G., Bianco, T. \& Tackley, P. Intraplate volcanism with complex age-distance patterns: A case for small-scale sublithospheric convection. Geochem. Geophys. Geosyst. 10, Q06015 (2009).
30. Koppers, A. A. P., Staudigel, H., Morgan, J. P. \& Duncan, R. A. Nonlinear ${ }^{40} \mathrm{Ar} /{ }^{39} \mathrm{Ar}$ age systematics along the Gilbert Ridge and Tokelau Seamount trail and the timing of the Hawaii-Emperor bend. Geochem. Geophys. Geosyst. 8, Q06L13 (2007).

31. Sandwell, D. T. \& Smith, W. H. F. Global marine gravity from retracked Geosat and ERS-1 altimetry: Ridge segmentation versus spreading rate. J. Geophys. Res. 114, B01411 (2009).

32. Müller, R. D., Dutkiewicz, A., Seton, M. \& Gaina, C. Seawater chemistry driven by supercontinent assembly, break-up and dispersal. Geology 41, 907-910 (2013).

33. Pearce, J. A. Geochemical fingerprinting of oceanic basalts with applications to ophiolite classification and the search for Archean oceanic crust. Lithos 100 14-48 (2008).

\section{Acknowledgements}

F. Jourdan is thanked for very useful comments and suggestions. We thank the captain, crew and members of the scientific party for a successful RV Sonne SO 142 (HULA II) Expedition. W. Lustenhouwer and S. Matveev performed the electron microprobe analyses. Financial support was provided by the German Federal Ministry of Education and Research (BMBF), The Netherlands Organisation for Scientific Research (NWO) and Australian Research Council grant DP0987713.

\section{Author contributions}

J.M.O'C., P.S. and J.P.M. conceived the project. J.P.M. and J.M.O'C. wrote the proposal that funded the original seagoing work. J.M.O'C., K.H., F.H. and J.R.W. designed and performed the experiments and data analysis. R.D.M., N.P.B. and D.T.S. provided supporting materials. J.M.O'C., K.H., R.D.M. and J.P.M. wrote the paper. W.J., P.S. and K.H. provided funding essential for carrying out the project.

\section{Additional information}

Supplementary information is available in the online version of the paper. Reprints and permissions information is available online at www.nature.com/reprints. Correspondence and requests for materials should be addressed to J.M.O'C.

\section{Competing financial interests}

The authors declare no competing financial interests. 